\title{
PENINGKATAN KETERAMPILAN MENULIS KARYA ILMIAH MELALUI LESSON STUDY
}

\author{
Siti Halidjah \\ Dosen Program Studi PGSD FKIP Universitas Tanjungpura \\ Jalan Prof.Dr.I I.I ladari Nawawi Pontianak 78124 \\ Email: sitihalidjah pgsduntan@yahoo.co.id
}

\begin{abstract}
Abstrak
Penelitian ini bertujuan untuk mendapatkan pemahaman yang mendalam tentang peningkatan keterampilan menulis makalah melalui lesson study pada mahasiswa Program Studi PGSD FKIP Untan. Penelitian ini menggunakan pendekatan penelitian tindakan yang dilakukan sebanyak dua siklus.Setiap siklus dilaksanakan empat kali pertemuan. Data dalam penelitian ini terdiri dari data kualitatif dan data kuantitatif. Data kualitatif diperoleh melalui lembar wawancara, kuesioner, dan lembar pengamatan. Data kuantitatif yang diperoleh dari hasil tes menulis makalah. Sumber data dalam penelitian adalah peristiwa pembelajaran menulis makalah melalui lesson study mahasiswa Program Studi PGSD FKIP Untan. Hasil penektian menunjukkan data awal nilai rata-rata keterampilan menulis makalah mahasiswa adalah 158,6 (kategori kurang). Setelah dilaksanakan pembelajaran dengan lesson study di siklus I, nilai rata-rata keterampilan menulis makalah meningkat menjadi 298,8 (kategori baik). Pada siklus II, nilai nilai rata-rata keterampilan menulis makalah mengalami peningkatan lagi menjadi 341,8 (kategori sangat baik). Hasil penelitian menunjukkan bahwa penggunaan lesson study dalam pembelajaran dapat meningkatkan keterampilan menulis karya ilmiah mahasiswa PGSD FKIP Untan.
\end{abstract}

Kata Kunci: Keterampilan menulis, karya ilmiah, lesson study

\begin{abstract}
This research aims to find a deep understanding of the improvement of scientific writing skills through lesson study on students of PGSD FKIP Untan. This research usesan action researchapproach in twocycles. The data in this research was divided into two, namely quantitative and qualitative. The qualitative data wereobtainedthrough interview, questionnaires, and observation sheets. The quantitative data wereobtained from the results of scientific writing test. The data in this research were the scientific writing learning through lesson study on the students of PGSD FKIP Untan. The results showed that the initial average score of students paper writing skill was 158.6 (average category). After learning through the lesson study in the first cycle, the average score of writing skills improved to 298.8 (good category). In the second cycle, the average score of paper writing skills also improved to 341.8 (very good category). The result indicates that the use of lesson study in learning can improve the scientific papers writing skills of PGSD students of FKIP Untan.
\end{abstract}

Keywords: Writing skills, scientific papers, lesson study

\section{PENDAHULUAN}

Keterampilan menulis berbeda dengan kemampuan menyimak dan bcrbicara, kemampuan menulis tidak diperoleh secara alamiah. Kemampuan menulis harus dipelajari dan dilatihkan dengan sungguh-sungguh.Kunci untuk dapat menulis adalah terus berlatih menuliskan ide, pikiran, dan gagasan dalam bentuk tulisan. Hal ini sejalan dengan pendapat Zainurrahman (2011:2) yang menyatakan bahwa latihan merupakan kunci yang paling utama demi mencapai kesuksesan untuk mencapai predikat "mampu menulis dengan baik dan benar".

Keterampilan menulis diperlukan dalam kehidupan sekarangini, namun pada kenyataannya masih banyak mahasiswa yang belum menguasai hal tersebut. Satu penyebabnya adalah adanya anggapan bahwa menulis merupakan kegiatan yang sulit dan membosankan. Oleh karena itu, mahasiswa perlu dibekaU dengan teori dan praktik menulis dalam kegiatan pembelajaran di kelas. 
Banyak mahasiswa yang merasakan masalah dalam menulis karya ilmiah khususnya makalah. Berdasarkan hasil pengamatan makalah yang ditulis mahasiswa, masalah yang dihadapi mahasiswa dalam menulis makalah adalah (1) kurang konsisten antara judul makalah dan isi makalah, (2) kurang tepat merumuskan masalah dan submasalah, (3) pembahasan tiap submasalah kurang terinci, (4) kajian pustaka ada yang kurang relevan dengan masalah dan submasalah, (5) simpulan belum mencermirikan uraian pembahasan masalah, (6) kurang memperhatikan penggunaan EYD, dan (7) tata cara penulisan belum mengikuti pedoman yang berlaku di FKIP Untan. Permasalahan tersebut muncul karena kegiatan menulis memang membutuhkan pikiran, waktu, serta perhatian yang sungguh-sungguh sehingga dianggap sebagai beban berat.

Penelitian ini berkaitan dengan proses pembelajaran menulis karya ilmiah. Penulisan karya ilmiah dalam penelitian ini difokuskan pada penulisan makalah. Pertimbangan memilih makalah sebagai karya ilmiah yang akan ditulis mahasiswa karena mulai dari semester pertama setiap tugas mata kuliah yang diberikan dosen berkaitan dengan pembuatan makalah. Umumnya dosen tidak memberikan atau menjelaskan sistematika pembuatan makalah. Kalaupun ada, sistematika yang diberikan tidak seragam.

Berkaitan dengan upaya meningkatkan kemampuan menulis karyailrniah bagi mahasiswa, seorang dosen dituntut meningkatkan kualitas pembelajaran yang akan dilakukannya, mulai dari tahap perencanaan sampai evaluasi. Satu kegiatan pembelajaran yang diyakini tepat yaitu melalui lesson study. Menurut Hendayana (2006:10), lesson study adalah suatu model pembinaan profesi pendidik melalui pengkajian secara kolabotarif dan berkelanjutan berlandaskan prinsip-prinsip kolegalitas dan mutual learning untuk membangun komunitas belajar. Menurut Hendayana (2006:10), lesson study bukan metode atau strategi pembelajaran tetapi kegiatan lesson study dapat menempatkan berbagai metode atau strategi pembelajaran sesuai dengan situasi, kondisi, dan permasalahan yang dihadapi dosen. Dengan lesson study, dosen dapat mengadakan pembelajaran dengan tertib. Dosen menyiapkan dan menyajikan pembelajaran dengan didampingi oleh kolega. Secara tidak langsung, pada saat yang bersamaan ketua jurusan dan ketua program studi menjalankan fungsinya sebagai supervisor pembelajaran di kelas.

Tahun 2010 Jurusan PMIPA FKIP Untan mendapat Hibah Perluasan Lesson Study di Perguruan Tinggi. Hibah perluasan tersebut melibatkan beberapa dosen Program Studi PGSD. Melihat dari efektivitas pelaksanaannya, peneliti tergerak untuk melakukan penelitian berkaitan dengan pelaksanaan lesson study di tingkat perguruan tinggi khususnya di Program Studi PGSD. Pelaksanaan lesson study yang diteliti yaitu yang berbasis program studi untuk meningkatkan keterampilan menulis karya ilmiah mahasiswa PGSD FKIP Untan.

Menurut Dalman (2012:149), makalah merupakan salah satu bentuk karya tulis ilmiah yang membahas sebuah gagasan/topik yang telah ditentukan dan wajib menaati sistematika penulisan ilmiah.Di dunia akademik, makalah sering dijadikan sebagai salah satu tugas yang harus dikerjakan mahasiswa. Hal ini sejalan dengan pendapat Djuharie (2001:8) yang menyatakan bahwa makalah adalah karya tulis ilmiah mengenai suatu topik tertentu yang tercakup dalam ruang lingkup suatu perkuliahan dan pendapat Arifin (2004:2) yang juga menyatakan bahwa makalah disusun biasanya untuk melengkapi tugas-tugas ujian mata kuHah tertentu atau untuk memberikan saran pemecahan tentang suatu masalah secara ilmiah.

Menurut Suyitno (2011:86), bagian inti makalah terdiri atas tiga pokok, yaitu (1) pendahuluan, (2) teks utama (gagasan-gagasan pokok yang akan dibahas), dan (3) penutup. Sudjana (1991:91-92) menyatakan bahwa menilai kualitas suatu makalah tidak dilihat dari tebal tipisnya makalah yang ditulis oleh penyusun makalah.

Menilai kualitas suatu makalah ilmiah tidak dilihat dari tebal tipisnya makalah yang ditulis oleh penyusun makalah. MenututSudjana makalah ilmiah dinilai berdasarkan kriteria (1) kesesuaian judul dan isi, (2) ketajaman perumusan masalah, (3) kebenaran pembahasan masalah, (4) ketepatan simpulan, dan (5) kebenaran tatatulis. Indikator yang clinilai pada suatu makalah menurut 
Nurjanah (2008:45) pada umumnya meliputi 4 (empat) macam, yaitu (a) penilaian terhadap pendahuluan, (b) penilaian terhadap teks utama, (3) penilaian terhadap penutup, dan (d) penilaian terhadap tampilan makalah.

Menurut Nurgiyantoro (2010:426), tugas menulis dalam arti yang sebenarnya, yaitu menulis untuk menghasilkan karya tulis. Berkaitan dengan tugas menulis makalah ilmiah, tugas menulis hendaknya bukan semata-mata untuk menghasilkan bahasa saja, melainkan bagaimana mengungkapkan gagasan dengan menggunakan bahasa tulis yang tepat juga mempertimbangkan bentuk, jenis, dan ragam tulisan. Untuk ragam tulisan ilmiah, satu diantaranya makalah ilmiah, komponen penilaiannya meliputi isi gagasan yang dikemukakan, organisasi isi, tata bahasa, gaya (pilihan struktur dan kosakata), serta ejaan dan tanda baca.

\section{Tabe1 1. Format Penilaian Makalah}

\begin{tabular}{|c|c|c|c|c|}
\hline No. & Komponen Penilaian & Bobot & Skor & Nilai \\
\hline \multirow[t]{3}{*}{ I } & Format Makalah & & & \\
\hline & \begin{tabular}{l|l}
1. & Sistematika penulisan
\end{tabular} & 5 & & \\
\hline & Ukuran kertas, jenis huruf, bidang pengetikan, dan format sampul & 5 & & \\
\hline \multirow{3}{*}{ II } & Bagian Pendahuluan & & & \\
\hline & Keterkaitan judul dengan latar belakang masalah & 10 & & \\
\hline & Ketepatan merumuskan masalah dan submasalah & 10 & & \\
\hline \multirow[t]{5}{*}{ III } & Bagian Isi & & & \\
\hline & Dukungan teori yang relevan & 10 & & \\
\hline & Sistematika jawaban masalah & 10 & & \\
\hline & $\begin{array}{l}\text { Keterkaitan antara submasalah yang satu dengan submasalah yang } \\
\text { lain }\end{array}$ & 10 & & \\
\hline & Ketuntasan pembahasan masalah. & 10 & & \\
\hline \multirow[t]{3}{*}{ IV } & Bagian Penutup & & & \\
\hline & \begin{tabular}{l|l}
1. & Simpulan
\end{tabular} & 10 & & \\
\hline & \begin{tabular}{l|l}
2. & Saran
\end{tabular} & 10 & & \\
\hline \multirow[t]{3}{*}{$\mathrm{V}$} & Tata Cara Penulisan & & & \\
\hline & Penggunaan bahasa & 5 & & \\
\hline & Teknik penulisan & 5 & & \\
\hline \multicolumn{2}{|c|}{ Jumlah } & 100 & & \\
\hline
\end{tabular}

Keterangan:

Rentangan Skor : 1, 2, 3, 4

Nilai : Bobot x Skor

Kriteria :

$\begin{array}{lll}\text { Baik Sekali (A) } & \text { : } & \text { Nilai } 321-400 \\ \text { Baik(B) } & : & \text { Nilai } 241-320 \\ \text { Cukup(C) } & : & \text { Nilai } 161-240 \\ \text { Kurang (D) } & : & \text { Nilai } 81-160 \\ \text { Sangat Kurang (E) } & : & \text { Nilai } 0-80\end{array}$


Mengacu dari ketiga pendapat di atas tentang kriteria keterampilan menulis makalah ilmiah dan dikaitkan dengan permasalahan yang dihadapi mahasiswa dalam penulisan makalah, berikut disajikan format keterampilan menulis makalah ilmiah yang digunakan dalam penelitian ini.

Menurut Hart (2011:1), lesson study adalah pengembangan profesional guru berbasis kolaborasi yang berasal dari Jepang. Untuk memperoleh pembelajaran maksimal, guru-guru di Jepang melaksanakan perencanaan dan evaluasi pembelajaran secara mendalam bersama guru lainnya.

Lesson study adalah model pembinaan profesi pendidik melalui pengkajian pembelajaran secara kolaboratif dan berkesinambungan, berlandaskan prinsip-prinsip kolegalitas dan mutual learning (saling belajar), untuk membangun komunitas belajar. Menurut Hendayana (2006:10), lesson study bukan metode atau strategi pembelajaran tetapi kegiatan lesson study dapat menerapkan berbagai metode/ strategi pembelajaran yang sesuai dengan situasi, kondisi, dan permasalahan yang dihadapi guru. Lesson study dilaksanakan dalam 3 (tiga) tahapan, yaitu plan (merencanakan), do (melaksanakan), dan see (merefleksi) yang berkelanjutan dan tak pernah beralchir (continuous improvement).

Kegiatan lesson study bermanfaat untuk meningkatkan kemampuan profesional dosen. Yang menarik dalam kegiatan ini adalah memanfaatkan kepakaran para dosen melalui kegiatan kerja sama untuk memperbaiki kinerja mengajar dengan memanfaatkan hasil pengamatan pelaksanaan tugas mengajar dalam pelaksanaan tugas yang sesungguhnya. Dengan melaksanakan kerja sama memperbaiki pelaksanaan tugas yang dilaksanakan langsung oleh para dosen akan sangat bermanfaat karena akan mengurangi tingkat kebergantungan para dosen dalam meningkatkan pengetahuan dan keterampilan terbaiknya melalui peningkatan pemahaman terhadap efektivitas kinerja belajar mahasiswa.

Lesson study menjadi penting karena kegiatan itu bermanfaat meningkatkan kemampuan dosen dalam menguasai materi pelajaran, meningkatkan keterampilan merencanakan pembelajaran, meningkatkan keterampilan menerapkan metode dan pelaksanaan pembelajaran secara umum, meningkatkan kemampuan dosen dalam melakukan pengamatan terhadap mahasiswa yang sedang melaksanakan belajar, meriingkafkan kemampuan kerja sama dengan teman sejawat serta dengan memperluas jaringan kerja, memperbaiki kinerja melalui pelaksanaan tugas sehari-hari dan membuka isolasi kelas sehingga peningkatan kemampuan diperoleh dengan tidak mengurangi hak mahasiswa untuk mendapat pelayanan belajar.

Menurut Hendayana (2006:39), "manfaat lesson study adalah (1) meningkatnya pengetahuan dosen tentang materi ajar dan pembelajarannya, (2) meningkatnya pemahaman dosen tentang cara mengobservasi aktivitas belajar mahasiswa, (3) menguatnya hubungan kolegalitas baik antardosen maupun dengan observer lain selain dosen, (4) menguatnya hubungan antara pelaksanaan pembelajaran sehari-hari dengan tujuan pembelajaran jangka panjang, (5) meningkatnya motivasi dosen untuk senantiasa berkembang, dan (6) meningkatnya kualitas rencana pembelajaran termasuk komponenkomponennnya seperti bahan ajar (teaching materials) dan strategi pembelajaran". Hasil kegiatan lesson study diharapkan dapat memberikan sumbangan yang besar terhadap peningkatan mutu pendidikan, dalam hal ini peningkatan mutu profesional dosen. Dengan demikian manfaat dari pelaksanaan lesson study dapat dijadikan acuan bagi peningkatan profesionalisme dosen.

Berdasarkan permasalahan dan kajian teori diatas, tujuan umum penelitian ini adalah untuk mendapatkan pemahaman yang mendalam tentang peningkatan keterampilan menulis makalah melalui lesson study pada mahasiswa Program Studi PGSD FKIP Untan. Tujuan umum tersebut dijabarkan menjadi beberapa tujuan khusus, yaitu (1) mendapatkan pemahaman yang mendalam tentang proses peningkatan keterampilan menulis makalah melalui lesson study dan (2) mendapatkan pemahaman yang mendalam tentang hasil keterampilan menulis makalah melalui lesson study. 


\section{METODE}

Penelitian ini menggunakan desain penelitian tindakan berupa penerapan lesson study untuk memecahkan masalah keterampilan menulis makalah. Penelitian dilaksanakan dalam dua siklus, tiap siklus dilaksanakan dalam empat kali pertemuan yang melibatkan langkah-langkah perencanaan, pelaksanaan tindakan, observasi, dan refleksi.

Data dalam penelitian ini dipilah menjadi 2 (dua), yaitu data kualitatif dan data kuantitatif. Data kualitatif diperoleh melalui lembar wawancara, kuesioner, dan lembar pengamatan, sedangkan data kuantitatif diperoleh dari hasil tes menulis makalah. Sumber data dalam penelitian ini adalah peristiwa pembelajaran menulis makalah melalui lesson study mahasiswa Program Studi PGSD FKIP Untan. Peneliti merupakan instumen kunci dalam penelitian, mulai dari tahap perencanaan, pelaksanaan, observasi, dan refleksi.

Jenis instrumen dalam penelitian ini adalah instrumen untuk mengukur proses dan hasil pembelajaran. Instrumen yang mengukur proses berupa pedoman observasi, pedoman wawancara, dan kuesioner, sedangkan instrumen yang mengukur produk atau hasil adalah tes menulis makalah.

Untuk mengetahui adanya peningkatan keterampilan menulis makalah mahasiswa melalui lesson study digunakan teknik analisis data kualitatif dan kuantitatif. Teknik analisis data kualitatif digunakan untuk menganalisis bagaimana peningkatan keterampilan menulis makalah melalui data hasil observasi, wawancara tertulis, dan penyebaran kuesioner, sedangkan teknik analisis data kuantitatif digunakan untuk menilai keterampilan mahasiswa menulis makalah.

\section{HASIL}

Tahap kegiatan penelitian diawali dengan kegiatan penyamaan persepsi. Kegiatan penyamaan persepsi dilaksanakan Sabtu 17 Agustus 2013 pukul 11.00 WIB bertempat di Pondok Sugeban Alianyang dihadiri semua tim pengamat, tahap ini bertujuan untakmenghindari kesalahan persepsi tentang lesson study. Tindak lanjut dari kegiatan penyamaan persepsi adalah memberikan tugas menulis makalah sebagai tes awal keterampilan menulis makalah. Tugas menulis makalah tersebut diberikan dengan rentangan tanggal 14-23 September 2013.

Tes awal keterampilan menulis karya ilmiah diberikan sebelum pelaksanaan tindakan. Tujuan diberikannya tes awal ini adalah (a) untuk menyiapkan mahasiswa dalam proses perkuliahan, dengan diberikannya tes awal maka pikiran mahasiswa akan terfokus pada tuntutan akhir mata kuliah yang disampaikan dan (b) untuk mengetahui kemampuan awal mahasiswa dalam menulis makalah dan dasar untuk menentukan peningkatan keterampilan yang dicapai pada siklus I dan siklus II.

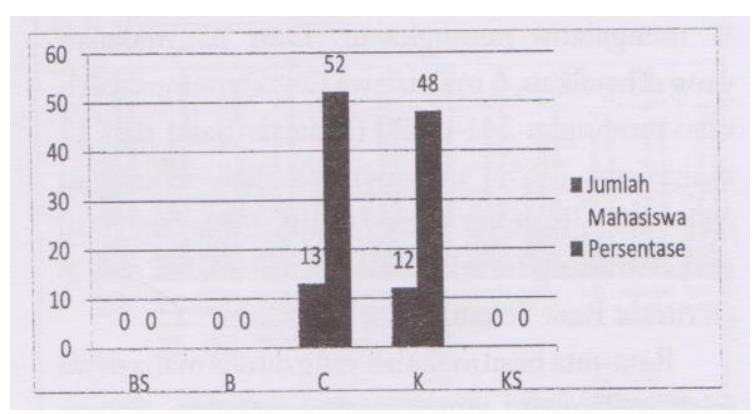

Grafik 1. Hasil Tes Awal Keterampilan Menulis Makalah

Hasil tes awal yang diberikan pada 25 mahasiswa menunjukkan bahwa terdapat 13 mahasiswa $(52 \%)$ yang memperoleh nilai $161-$ 240 (Kriteria Cukup) dan 12 mahasiswa (48\%) yang memperoleh nilai 81-160 (Kriteria Kurang). Rata-rata keterampilan menulis makalah dari hasil tes awal adalah 158,5 (Kriteria Kurang). Dengan demikian dapat disimpulkan bahwa keterampilan mahasiswa dalam menulis makalah tergolong rendah.

Hasil keterampilan menulis makalah siklus I mengalami peningkatan. Nilai yang diperoleh 25 mahasiswa $(100 \%)$ berada di rentangan $241-$ 320 dengan nilai rata— rata 298,8 (Kriteria Baik). Namun, apabila dilihat dari persentase ketuntasan tiap-tiap komponen dari 12 sub komponen yang mencapai kriteria ketuntasan hanya 5 subkomponen, artinya belum mencapai $50 \%$ dari jumlah subkomponen. Untuk lebih jelas, hasil keterampilan menulis makalah siklus I dapat dilihat pada grafik berikut ini. 


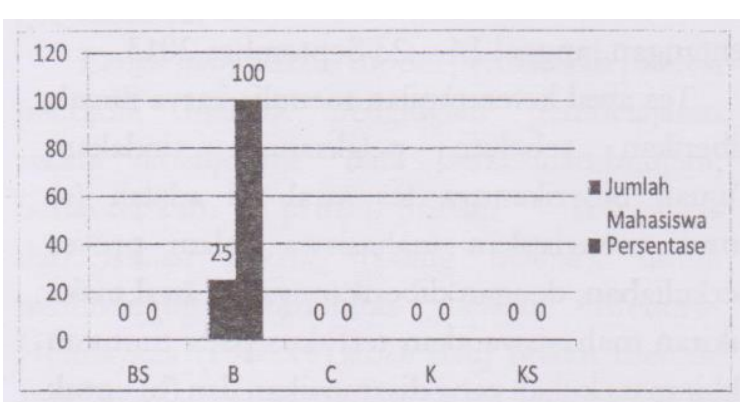

Grafik 2. Hasil Tes Siklus I Keterampilan Menulis Makalah

Hasil keterampilan menulis makalah siklus II mengalami peningkatan. Dari 25 makalah yang dihasilkan, 6 mahasiswa (24\%) memperoleh nilai rentangan 241-320 (Kriteria Baik) dan 19 mahasiswa $(76 \%)$ memperoleh nilai rentangan 321-400 (Kriteria Baik Sekali). Rata-rata hasil makalah yang ditulis mahasiswa adalah 341,8 (Kriteria Baik Sekali).

Rata-rata hasil makalah yang ditulis mahasiswa telah melampaui target yang rencanakan. Secara rinci hasil keterampilan menulis makalah dapat dilihat pada grafik berikut ini.

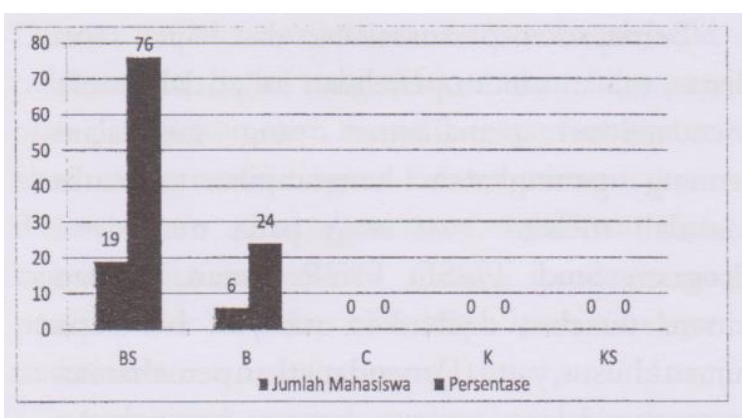

Grafik 3. Hasil Tes Siklus II Keterampilan Menulis Makalah

\section{PEMBAHASAN}

Penelitian ini adalah penelitian tindakan yang bertujuan untuk meningkatkan keterampilan menulis makalah mahasiswa melalui lesson study. Indikator keberhasilan dalam penelitian ini tidak semata-mata difokuskan pada hasil makalah yang ditulis mahasiswa. Semua data yang berhuburigan dengan proses pembelajaran yang kurang berjalan maksimal menjadi acuan untuk melakukan perbaikan pada proses pembelajaran pada pertemuan berikutnya. Hal ini dilakukan dengan harapan keterampilan menulis makalah mahasiswa dapat terus ditingkatkan.

Hasil penelitian berkaitan dengan perencanaan pembelajaran menulis makalah melalui lesson study menunjukkan bahwa perencanaan pembelajaran disusun secara kolaboratif antara dosen sebagai peneliti dengan tim pengamat yang terdiri dari dosen dan mahasiswa. Sebelum perencanaan dimulai, dosen sebagai peneliti melakukan kegiatan penyamaan persepsi dengan tim pengamat penelitian. Penyusunan perencanaan pembelajaran menulis makalah melalui lesson study membantu dosen mengelola pembelajaran secara sistematis. Selain itu, perencanaan pembelajaran dapat mengarahkan aktivitas mahasiswa dalam setiap tahap kegiatan pembelajaran. Dalam lesson study, fokus yang diamati adalah proses kegiatan mahasiswa. Apapun yang dilakukan mahasiswa dalam kegiatan pembelajaran mencerrninkan bagaimana dosennya mengajar. Keberhasilan dosen dalam menyampaikan materi tercermin dari hasil belajar yang diperoleh mahasiswa. Dalam lesson study, dosen memijiki kesempatan menerapkan berbagai metode pembelajaran dan memilih media pembelajaran yang sesuai dengan materi yang disampaikan.

Lesson study membuka peluang bagi dosen untuk terus memperbaiki kualitas pembelajaran. Pembelajan menulis karya ilmiah yang dipadukan dengan lesson study merupakan satu cara yang tepat dalam meningkatkan keterampilan menulis makalah mahasiswa PGSD FKIP Untan. Kondisi pembelajaran yang dirancang dengan melibatkan beberapa tim pengamat dapat merekam dengan jelas peristiwa pembelajaran yang terjadi di dalam kelas. Data yang berkaitan dengan kegiatan pembelajaran dicatat oleh masing-masing pengamat dan dibahas setelah pembelajaran selesai.

Pembelajaran menulis makalah melalui lesson study memberikan keuntungan bagi dosen dalam hal merancang pembelajaran, melaksanakan, dan merefleksi karena dilakukan secara berkolaborasi dengan teman sesama dosen. Dosen dapat merancang pembelajaran secara optimal dengan memperhatikan dan mempertimbangkan karakteristik belajar mahasiswa. Proses pembelajaran di kelas tidak 
hanya diketahui oleh dosen yang mengajar, tetapi juga teman dosen yang menjadi pengamat pembelajaran. Peristiwa pembelajaran diamati sehingga dosen dapat mengetahui kelebihan dan kelemahannya mengajar dari refleksi yang dilakukan setelah kegiatan pembelajaran selesai.

Kegiatan pembelajaran dalam satu siklus dirancang dan dilaksanakan dalam 4 kali pertemuan dan dilanjutkan dengan kegiatan refleksi bersama antara dosen pengajar dengan tim pengamat. Selain melalui pengamatan tim pengamat, semuaperistiwapembelajarandirekam oleh tim dokumentasi. Fungsi perekaman ini untuk mencocokkan data yang diperoleh dari tim pengamat. Hal ini diperkuat dengan pendapat Hendayana (2006:56) yang mengatakan bahwa rekaman video ini sangat penting sebagai bagian dari dokumentasi yang sewaktu-waktu dapat dijadikan sebagai bahan acuan untuk melakukan diskusi pengembangan lesson study atau diskusi masalah-masalah pembelajaran secara umum.

Penelitian ini adalah penelitian tindakan yang bertujuan untuk meningkatkan keterampilan menulis makalah mahasiswa melalui lesson study. Indikator keberhasilan dalam penelitian ini tidak semata-mata difokuskan pada hasil makalah yang ditulis mahasiswa. Semua data yang berhubungan dengan proses pembelajaran yang kurang berjalan maksimal menjadi acuan untuk melakukan perbaikan pada proses pembelajaran di pertemuan berikutnya. Hal ini dilakukan dengan harapan keterampilan menulis makalah mahasiswa dapat terus ditingkatkan.

Berikut ini disajikan rekapitulasi hasil keterampilan menulis makalah mulai dari prasiklus, siklus I dan siklus II.

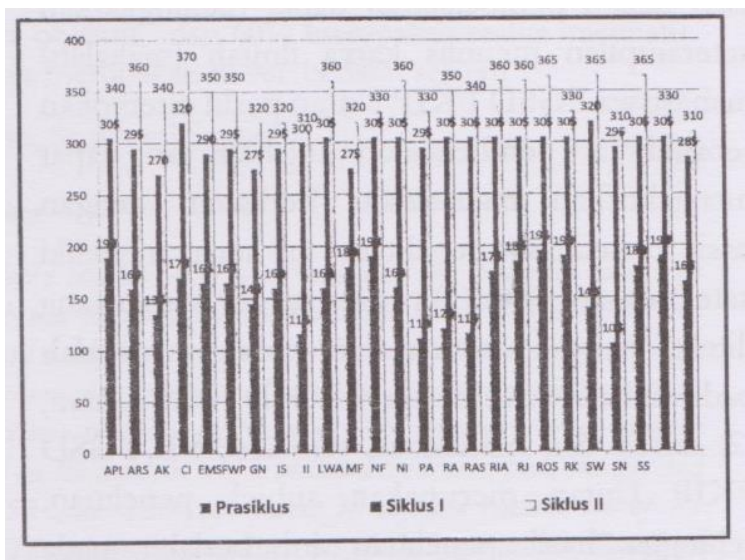

\section{Grafik 4. Rekapitulasi Hasil Keterampilan Menulis Makalah Permahasiswa}

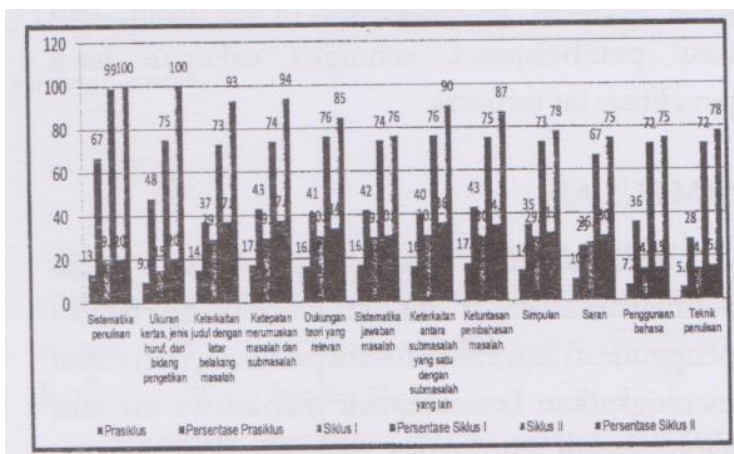

Grafik 5. Rekapitulasi Hasil Keterampilan Menulis Makalah Peraspek

Dari grafik di atas dapat dilihat peningkatan keterampilan menulis makalah mahasiswa. Data awal nilai rata-rata keterampilan menulis makalah mahasiswa adalah 158,6 (kriteria kurang) dengan rincian 12 orang $(48 \%)$ mendapat nilai pada rentangan 81-160 (kriteria kurang) dan 13 orang (52\%) mendapat nilai pada rentangan 161-240 (kriteria cukup). Siklus I, nilai rata-rata keterampilan menulis makalah meningkat menjadi 298,8. Hasil keterampilan menulis makalah di siklus I termasuk kriteria baik karena berada pada rentangan nilai 241-320. Pada siklus II, nilai nilai rata-rata keterampilan menulis makalah mengalami peningkatan lagi menjadi 341,8 dengan rincian 6 orang $(24 \%)$ mendapat nilai pada rentangan $241-320$ (kriteria baik) dan 19 orang (76\%) mendapat nilai pada rentangan 321-400 (kriteria sangat baik). Dengan demikian, penggunaan lesson study dalam pembelajaran dapat meningkatkan keterampilan menulis karya ilmiah (makalah) mahasiswa PGSD FKIP Untan perlu diterapkan sebagai suatu pembelajaran yang baik, yang dapat mengaktifkan mahasiswa. Berkaitan dengan hasil penelitian, penelitian ini juga memiliki keterbatasan, yaitu (1) proses pembelajaran yang diteliti hanya pembelajaran menulis makalah pada mahasiswa semester V PGSD FKIP Untan, (2) dosen dan mahasiswa semester VB PGSD FKIP Untan merupakan subjek penelitian, sehingga hasil penelitian ini berlaku pada mahasiswa lain yang berkarakteristik sama, dan (3) pembelajaran menulis makalah difokuskan pada kegiatan 
perencanaan, pelaksanaan, dan hasil pembelajaran, sehingga cakupan hasil penelitian ini terbatas.

\section{SIMPULAN}

Berdasarkan hasil penelitian dan pembahasan dapat ditarik kesimpulan bahwa penggunaan lesson study dalam pembelajaran dapat meningkatkan keterampilan mahasiswa menulis karya ilmiah khususnya makalah. Peningkatan ini tampak pada perencanaan, pelaksanaan, dan hasil pembelajaran yang telah dilaksanakan.

\section{DAFTAR PUSTAKA}

Creswell, John W. 2010. Research Design: Pendekatan Kualitatif, Kuantitatif, dan Mixed terjemahan Ahmad Fawaid. Yogyakarta: Pustaka Pelajar.

Dalman. 2012. Menulis Karya Ilmiah. Jakarta: RajaGrafindo Persada.

Djuharie, O. Setiawan dan Suherli. 2001. Panduan Membuat Karya Tulis. Bandung: Yrama Widya.

Hart, Lynn C, 2011. Alice Alston, Aki Murata. Lesson Study Research and Pratice in
Mathematics Education. New Jersey: Springer.

Hendayana, Sumar. Dkk. 2006. Lesson Study: Suatu Strategi untuk Meningkatkan Keprofesionalan Pendidik. Bandung: UPI Press.

Ishak dan Ugi Suprayogi. 2012. Penelitian Tindakan dalam Pendidikan Nonformal. Jakarta: PT RajaGrafindo Persada.

Miles, Matthew B. dan A. Michael Huberman. 1992. Analisis Data Kualitatif terjemahan Tjetjep Rohendi Rohidi. Jakarta: Ul-Press. Nurjanah, Nunuy. "Menulis Karya Ilmiah'_। http://ebookbrowse.com/men-kar-ilmiahpdf-dl 97228163 (diakses 17 April 2013).

Sudjana, Nana. 1987. Tuntunan Penyusunan Karya Ilmiah: Makalah, Skripsi, Tesis, Disertasi._Bandung: Sinar Baru.

Sugiyono. 2014. Metode Penelitian Kuantitatif, Kualitatif, dan Kombinasi (Mixed Methods). Bandung: Alfabeta.

Suyitno, Imam. 2011. Karya Tulis Ilmiah (KTI) Panduan, Teori, Pelatihan, dan Contoh. Bandung: PT Refika Aditama.

Tim Dosen PGSD. 2009. Etika Program Studi: Program Studi PGSD Jurusan Pendidikan Dasar. Pontianak: Percetakan Mulia.

Zainurrahman. 2011. Menulis: Dari Teori Hingga Praklik (PenawarRacun Plagiarisme). Bandung: Alfabeta. 